\title{
$\alpha$-Conotoxin MII Blocks Nicotine-Stimulated Dopamine Release in Rat Striatal Synaptosomes
}

\author{
Jennifer M. Kulak, ${ }^{1}$ Thu A. Nguyen, ${ }^{1}$ Baldomero M. Olivera, ${ }^{1}$ and J. Michael McIntosh ${ }^{1,2}$ \\ Departments of ${ }^{1}$ Biology and ${ }^{2}$ Psychiatry, University of Utah, Salt Lake City, Utah, 84112
}

Activation of presynaptic nicotinic acetylcholine receptors (nAChRs) can induce the release of neurotransmitters such as dopamine and norepinephrine in the CNS. Accumulating evidence suggests that distinct $n A C h R$ subtypes are involved; however, it has been difficult to determine the subunit composition of these receptors, in part because of the lack of a sufficient variety of selective $\mathrm{nAChR}$ ligands. We present experimental data that at least two different $n A C h R$ complexes are involved in dopamine release, one of which has an $\alpha 3 / \beta 2$ subunit interface.

The recently discovered peptide $\alpha$-conotoxin MII is a potent and selective inhibitor of rat nAChRs containing an interface formed by $\alpha 3$ and $\beta 2$ subunits. We used this peptide to examine nicotine-stimulated release of dopamine from rat striatal synaptosomes and of norepinephrine from hippocampal syn- aptosomes. MII (100 nM) blocks $34-49 \%$ of the nicotinestimulated dopamine release, but not dopamine release evoked by elevated $\left[\mathrm{K}^{+}\right]$. Furthermore, two peptides structurally related to $\alpha$-conotoxin MII, namely $\alpha$-conotoxin MI (selective for $\alpha 1 \beta 1 \gamma \delta$ nAChRs) and $\alpha$-conotoxin ImI (selective for $\alpha 7$ containing $\mathrm{nAChRs}$ ), have no effect on nicotine-stimulated dopamine release. The results indicate that one third to half of the dopamine release in the striatal preparation is mediated by $\mathrm{nAChRs}$ with an $\alpha 3 / \beta 2$ subunit interface. In contrast, $\leq 10 \%$ of nicotine-stimulated release of norepinephrine from hippocampal synaptosomes is modulated by nAChRs with $\alpha 3 / \beta 2$ subunit interfaces.

Key words: $\alpha$-conotoxin MII; dopamine release; striatum; nicotine; $\alpha 3 \beta 2$ receptor; acetylcholine; norepinephrine release; hippocampus
Modulation of dopamine-mediated neurotransmission is believed to be fundamental to the addicting properties of substances such as cocaine, amphetamine, and morphine (Koob, 1992; Di Chiara, 1995). Striking evidence has been obtained recently that nicotine's addictive properties are highly mechanistically related to these drugs of abuse. Specifically, nicotine activation of presynaptic nicotinic acetylcholine receptors (nAChRs) releases dopamine in critical brain reward circuits (Pontieri et al., 1996). Nicotine-stimulated dopamine release has been demonstrated in vitro; however, there has not been a definitive characterization of the relevant molecular components.

nAChRs are believed to be heteropentameric ion channel complexes generally composed of two or more different subunits ( $\alpha$ and $\beta$ ). Molecular data indicate that the mammalian CNS has a variety of different $\mathrm{nAChR}$ subunits. To date, seven different $\alpha$ subunits $(\alpha 2-\alpha 7, \alpha 9)$ and three different $\beta$ subunits $(\beta 2-\beta 4)$ have been defined by cloning.

Although the presence of nAChRs on cell soma and dendrites has been recognized for some time, more recent data have demonstrated their presence on presynaptic terminals (Wonnacott, 1997). Activation of these presynaptic nAChRs can induce neurotransmitter release. Thus, nicotinic agonists have been shown to elicit the release of several different neurotransmitters, including dopamine from striatum and frontal cortex (Rapier et al., 1988;

Received March 11, 1997; revised April 8, 1997; accepted April 23, 1997.

This work was supported by National Institutes of Health Grants MH 53631 and GM 48677 and Scientist Development Award for Clinicians MH 00929 (J.M.M.). We are indebted to Paul Clarke, Doju Yoshikami, and G. Edward Cartier for generous advice and assistance. We also thank Dianna Wilkins for assistance with statistical analysis.

Correspondence should be addressed to Dr. J. Michael McIntosh, 201 S. Biology Building, Salt Lake City, UT 84112.

Copyright (C) 1997 Society for Neuroscience $0270-6474 / 97 / 175263-08 \$ 05.00 / 0$
Grady et al., 1992; El-Bizri and Clarke, 1994), norepinephrine from hippocampus (Rowell and Winkler, 1984; Wilkie et al., 1993; Sacaan et al., 1995; Clarke and Reuben, 1996), glutamate from cortex, medial habenula nucleus, and hippocampus (Vidal and Changeux, 1993; McGehee and Role, 1995; Gray et al., 1996), GABA from interpeduncular nucleus (Mulle et al., 1991), and acetylcholine from cortex and hippocampus (Rowell and Winkler, 1984; Lapchak et al., 1989).

Interestingly, it appears that distinct subtypes of presynaptic nAChRs regulate the release of different neurotransmitters. For example, nicotine-stimulated glutamate and acetylcholine release is blocked by $\alpha$-bungarotoxin, suggesting that these nAChRs possess an $\alpha 7$ subunit (McGehee and Role, 1995). In contrast, nicotine-stimulated dopamine release is not blocked by $\alpha$-bungarotoxin (Grady et al., 1992). Furthermore, the nAChRs modulating norepinephrine release differ pharmacologically from those modulating the release of glutamate, acetylcholine, or dopamine (Sacaan et al., 1995; Clarke and Reuben, 1996).

The modulation of dopamine release by nicotinic acetylcholine circuitry is of central importance because of its significance for problems of addiction as well as because of its relevance to psychosis. However, the specific nAChR subtype(s) that mediates dopamine release remain unidentified. A major operational obstacle has been the lack of subtype-specific ligands. In this report, we describe the use of the newly characterized $\alpha$-conotoxin MII (Cartier et al., 1996a,b; Harvey et al., 1997), a peptide that potently and selectively blocks $\alpha 3 \beta 2 \mathrm{nAChRs,} \mathrm{to} \mathrm{investigate}$ nicotine-induced dopamine release. The results indicate that at least two different $\mathrm{nAChR}$ receptor complexes may mediate striatal dopamine release and that one of these receptors contains an $\alpha 3 / \beta 2$ subunit interface. 


\section{MATERIALS AND METHODS}

Materials. $\left[{ }^{3} \mathrm{H}\right]$ dopamine $(\sim 30 \mathrm{Ci} / \mathrm{mmol})$ (dihydroxyphenyl-ethylamine, $\left.3,4\left[7_{-}^{3} \mathrm{H}\right]\right)$ and $\left[{ }^{3} \mathrm{H}\right]$ norepinephrine $(\sim 42 \mathrm{Ci} / \mathrm{mmol})$ (norepinephrine, levo-[ring-2,5,6- $\left.{ }^{3} \mathrm{H}\right]$ ) were obtained from Dupont NEN, Boston, MA (\#NET-131 and \#NET-678, respectively). ${ }^{3} \mathrm{H}$-labeled radioligands were aliquoted in 5 and $14.1 \mu \mathrm{Ci}$ amounts, respectively, and stored under argon at $-80^{\circ} \mathrm{C}$. ( -$)$ Nicotine hydrogen tartrate was obtained from Sigma (St. Louis, MO; \#N5260). Pargyline HCl (\#D-026) and mecamylamine $\mathrm{HCl}$ (\#M-106) were from obtained from Research Biochemicals International (Natick, MA). Before use, all drugs were prepared fresh in superfusion buffer (SB) consisting of (in $\mathrm{mM}$ ): $128 \mathrm{NaCl}, 2.4 \mathrm{KCl}, 3.2$ $\mathrm{CaCl}_{2}, 1.2 \mathrm{KH}_{2} \mathrm{PO}_{4}, 0.6 \mathrm{MgSO}_{4}, 25 \mathrm{HEPES}, 10 \mathrm{D}$-glucose, $1 \mathrm{~L}$-ascorbic acid, and 0.1 pargyline, and $0.1 \mathrm{mg} / \mathrm{ml} \mathrm{BSA}, \mathrm{pH}$ adjusted to 7.5 with $\mathrm{NaOH} . \alpha$-Conotoxin MII was synthesized as described previously (Cartier et al., 1996a).

Methods. Male Sprague Dawley rats, weighing 200-400 gm, were maintained on a 12:12 hr light/dark cycle. Rats were drug-naive and housed three per cage, and food and water were available ad libitum.

Synaptosomal preparation and ${ }^{3} \mathrm{H}$-labeled radioligand preloading. Synaptosomes were prepared essentially as described by Clarke and coworkers (El-Bizri and Clarke, 1994; Clarke and Reuben, 1996). For each experiment, two rats were decapitated, and both striata or hippocampi from each (total wet tissue weight $180-240 \mathrm{mg}$ ) were excised immediately and dissected on an ice-chilled platform and placed in dissection buffer consisting of $0.32 \mathrm{M}$ sucrose and $5 \mathrm{~mm}$ HEPES, adjusted to $\mathrm{pH} 7.5$ with $\mathrm{NaOH}$. Unless otherwise indicated, buffers used in the synaptosomal preparation were at $4^{\circ} \mathrm{C}$. Tissues were homogenized in dissection buffer $(0.02 \mathrm{ml} / \mathrm{mg}$ wet tissue weight) by $12 \mathrm{up}$-and-down strokes of a $0.25 \mathrm{~mm}$ clearance glass Teflon homogenizer operating at $900 \mathrm{rpm}$. The homogenate was centrifuged at $1000 \times g$ for $10 \mathrm{~min}$ at $4^{\circ} \mathrm{C}$. The pellet was discarded, and the supernatant was recentrifuged at $12,000 \times g$ for 20 $\min$ at $4^{\circ} \mathrm{C}$. The final crude $\mathrm{P} 2$ synaptosomal fraction was resuspended in $\mathrm{SB}(0.5 \mathrm{ml} / 100 \mathrm{mg}$ wet tissue weight $)$ containing $0.12 \mu \mathrm{M}\left[{ }^{3} \mathrm{H}\right]$ dopamine for striatal tissue or $0.2 \mu \mathrm{M}\left[{ }^{3} \mathrm{H}\right]$ norepinephrine for hippocampal tissue and incubated at $37^{\circ} \mathrm{C}$ for $10 \mathrm{~min}$. The loaded synaptosomes were centrifuged at $1000 \times g$ for $5 \mathrm{~min}$ at room temperature $\left(24^{\circ} \mathrm{C}\right)$, and the pellet was resuspended gently in $2.0 \mathrm{ml}$ of SB. For "calcium-free" release studies, $\mathrm{CaCl}_{2}$ in the SB was replaced by $3.2 \mathrm{mM} \mathrm{MgCl}_{2}$ and $2.25 \mathrm{~mm}$ $\mathrm{Na}_{4}$ EGTA before adjusting $\mathrm{pH}$. For high $\left[\mathrm{K}^{+}\right]$-labeled stimulated release solution, $\left[\mathrm{K}^{+}\right]$was elevated by $20 \mathrm{~mm}$.

Superfusion. The assay system had 12 identical channels. Each channel had a length of $0.8 \mathrm{~mm}$ intradermal Teflon tubing (\#5-8696, Supelco, Bellefonte, PA) connected to a three-way subminiature solenoid valve (\#161T031, Neptune Research, West Caldwell, NJ), which was used to switch in pulses of buffer containing nicotine or $20 \mathrm{~mm} \mathrm{KCl}$. Teflon tubing connected the solenoid valve to a stainless steel filter unit (\#09753-10A, Fisher, Houston, TX) through a Teflon PTFE male luer adapter (\#DN-06391-90, Cole-Parmer, Niles, IL). Each filter unit was filled with a $13 \mathrm{~mm}$ diameter A/E glass fiber filter (\#09-730-51, Fisher) to catch the synaptosomes. The outlet port of the filter unit was connected to a peristaltic pump (\#H-07553-70, Cole-Parmer) by platinumcured silicone tubing (\#H-96410-13, Cole-Parmer). The pump continuously pulled the superfusate through the filter at a rate of $0.5 \mathrm{ml} / \mathrm{min}$. Teflon tubing and Teflon-coated parts were used upstream of the synaptosomes to avoid plasticizers such as Tinuvin 770 (a common light and UV radiation stabilizer used in a wide range of plastics) known to block neuronal nAChRs (Papke et al., 1994).

The 12 channel system enabled several assays to be performed in parallel simultaneously. Before loading the filters with synaptosomes, channels were rinsed with distilled water and then superfusate buffer (SB alone or SB plus antagonist), with care taken to ensure that the tubing leading to the three-way solenoid switching valve was fully loaded with superfusate buffer plus agonist (nicotine or $\mathrm{KCl}$ ). Then $2 \mathrm{ml}$ of the ${ }^{3} \mathrm{H}$-labeled radioligand-loaded synaptosomes were diluted fourfold with SB and pumped into the filtration apparatus.

After a preliminary superfusion period of $20 \mathrm{~min}$, seventeen $2 \mathrm{~min}$ fractions per channel were collected in polypropylene minivials (\#2060, Outpatient Services, Petaluma, CA) containing $4.0 \mathrm{ml}$ of scintillation fluid (\#88245305, Cytoscint, ICN Pharmaceuticals, Costa Mesa, CA). After an initial collection period of 11-12 min, a $1 \mathrm{~min}(0.5 \mathrm{ml})$ pulse of SB with or without agonist was delivered simultaneously to all channels by switching on the solenoids. After the collection period, the filters holding the synaptosomes were removed to determine the residual radioactivity. A liquid scintillation counter (Beckman LS9800, 57.2\% efficiency) was used to monitor tritium levels.
Data analysis. It has been shown previously that tritium released by $\mathrm{nAChR}$ agonists or by depolarizing concentrations of $\mathrm{KCl}$ is directly proportional to total radioligand released (Rapier et al., 1988). Thus, throughout this paper, levels of tritium release is assumed to correspond directly to amounts of radioligand release.

Release is calculated as (dpm in the peak fractions minus the baseline release)/baseline release. Baseline release is defined as the average of two pre- and two postrelease fractions. Release is normalized as a percentage of total agonist-stimulated release. Agonist-stimulated release with superfusate containing different $\alpha$-conotoxin concentrations was compared with that of controls without toxin and analyzed for statistically significant mean differences using a $t$ test on raw (nonnormalized) data with SPSS software (SPSS, Chicago, IL).

\section{RESULTS}

\section{The effects of $\alpha$-conotoxin MII on nicotine-stimulated $\left[{ }^{3} \mathrm{H}\right]$ dopamine release}

(-)-Nicotine has been shown previously to increase $\left[{ }^{3} \mathrm{H}\right]$ dopamine release from rat striatal synaptosomes in a concentrationdependent manner with an estimated $\mathrm{EC}_{50}$ of $1.6 \times 10^{-7} \mathrm{M}$ (El-Bizri and Clarke, 1994). As shown in Figure 1, nicotine (3 $\mu \mathrm{M})$ stimulates the release of $\left[{ }^{3} \mathrm{H}\right]$ dopamine. Furthermore, the release is calcium-dependent and fully blocked by the nonselective, noncompetitive antagonist mecamylamine.

As shown in Figure $1 E, \alpha$-conotoxin MII blocked part, but not all, of $3 \mu \mathrm{M}$ nicotine-stimulated $\left[{ }^{3} \mathrm{H}\right]$ dopamine release. This block was dose-dependent and statistically significant at concentrations $\geq 1 \mathrm{~nm}$ (Fig. 2). $\alpha$-Conotoxin MII (100 nM) produced $34 \%$ block. This partial block was seen in 13 separate synaptosomal preparations (43 data points) and was highly significant ( $p<$ 0.001 ). One micromolar MII, however, failed to produce significantly more block than $100 \mathrm{~nm}$ MII $(p=0.2)$, suggesting that maximum (selective) block was achieved at $\leq 100 \mathrm{~nm}$ concentration. At low nanomolar concentrations, $\alpha$-conotoxin MII has been shown to be specific for rat $\alpha 3 \beta 2$ receptors expressed in Xenopus oocytes $\left(\mathrm{IC}_{50}=0.5 \mathrm{nM}\right)$. At concentrations $>100 \mathrm{nM}$, $\alpha$-conotoxin MII begins to have measurable effects on other oocyte-expressed $\mathrm{nAChR}$ subtypes. For example, the $\mathrm{IC}_{50}$ value for $\alpha 4 \beta 2 \mathrm{nAChRs}$ (the $\alpha / \beta$-type receptor with the next highest affinity for $\alpha$-conotoxin MII) is $\sim 400 \mathrm{nM}$ (Cartier et al., 1996a,b; Harvey et al., 1997). Thus, these results indicate that $\alpha$-conotoxin MII blocks nicotine-stimulated dopamine release by blocking nAChRs with an $\alpha 3 / \beta 2$ subunit interface (see Discussion).

\section{$\alpha$-Conotoxin MII effects on depolarization-induced release; effect of other $\alpha$-conotoxins on nicotine- stimulated dopamine release}

To investigate further the specificity of the block of release by $\alpha$-conotoxin MII, we next assessed its effects on elevated $\left[\mathrm{K}^{+}\right]$induced dopamine release. Striatal synaptosomes were loaded with $\left[{ }^{3} \mathrm{H}\right]$ dopamine and preincubated for $20 \mathrm{~min}$ with or without $\alpha$-conotoxin MII. Synaptosomes were then depolarized with a 1 min pulse of SB that contained high $(22.4 \mathrm{~mm})\left[\mathrm{K}^{+}\right]$with or without toxin. $\left[\mathrm{K}^{+}\right]$-stimulated release under control conditions was defined as $100 \%$. $\alpha$-Conotoxin MII (100 nM), which significantly blocks nicotine-stimulated dopamine release, had no effect on depolarization-stimulated dopamine release $(106 \pm 4 \%, p=$ $0.3)$. The experiment was performed three times with six replicates per experiment.

Next, we tested to determine whether structurally related $\alpha$-conotoxins that target non- $\alpha 3 \beta 2$ nicotinic subtypes (Table 1 ) could also block nicotine-stimulated dopamine release. Neither $\alpha$-conotoxin MI, a toxin specific for the muscle subtype of nicotinic receptor, nor $\alpha$-conotoxin ImI, which is specific for the $\alpha 7$ 

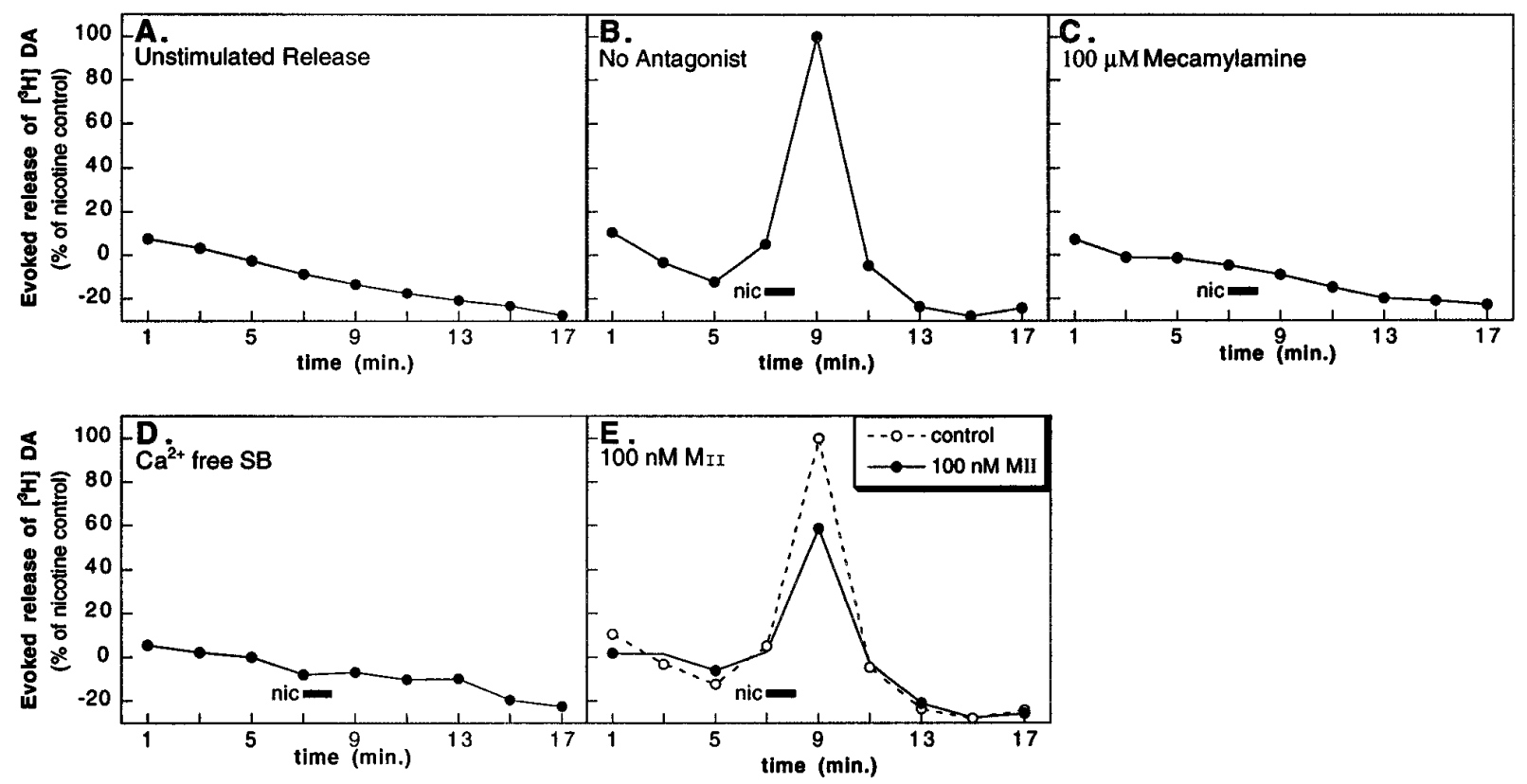

Figure 1. Nicotine-stimulated dopamine $(D A)$ release. Rat striatal synaptosomes loaded with $\left[{ }^{3} \mathrm{H}\right]$ dopamine were perfused with SB with or without antagonist for $20 \mathrm{~min}$ before sample collection. The amount of $\left[{ }^{3} \mathrm{H}\right]$ dopamine release at $t=9$ min in the absence of nicotine pulse is defined as zero, and the nicotine-stimulated release is defined as $100 \%$. Data are plotted on the $x$-axis as the time midpoint of each fraction. $A$, Unstimulated release of $\left[{ }^{3} \mathrm{H}\right]$ dopamine. $B,\left[{ }^{3} \mathrm{H}\right]$ dopamine released by a $1 \mathrm{~min}$ pulse of $3 \mu \mathrm{M}$ nicotine (horizontal bar in this and all subsequent panels). $C$, Mecamylamine (100 $\mu \mathrm{M}$ ) blocked all of the nicotine-evoked $\left[{ }^{3} \mathrm{H}\right]$ dopamine release. $D$, No nicotine-stimulated release of dopamine was evident when $\mathrm{Ca}{ }^{2+}$ is absent from the $\mathrm{SB}\left(\mathrm{CaCl}_{2}\right.$ replaced by equimolar $\mathrm{MgCl}_{2}$ and $2.25 \mathrm{~mm} \mathrm{Na}{ }_{4}$ EGTA added). $E$, MII (100 nM) blocked $40 \%$ of nicotine-stimulated [ ${ }^{3} \mathrm{H}$ ]dopamine release.

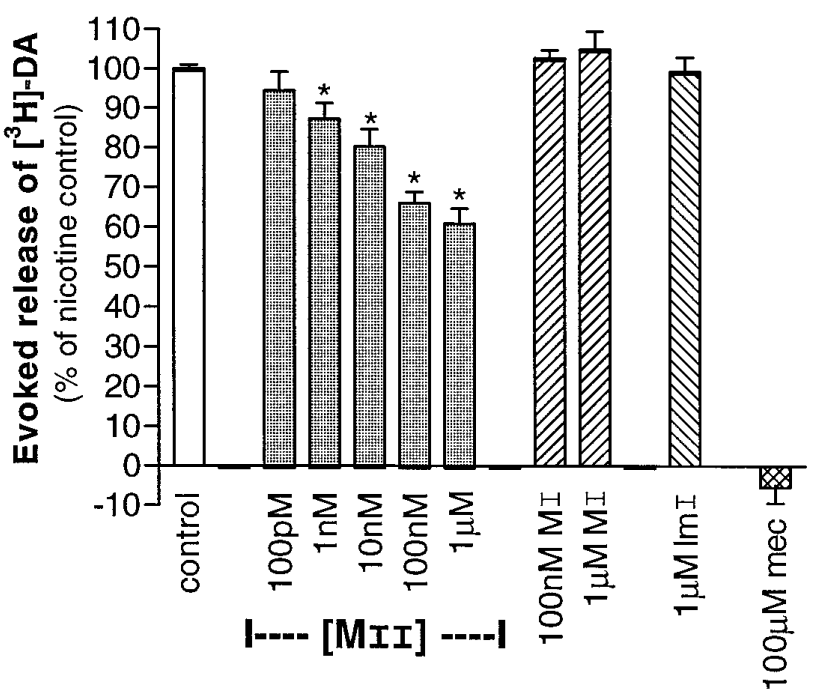

Figure 2. $\alpha$-Conotoxin MII blocks nicotine-evoked dopamine release. Rat striatal synaptosomes were loaded with $\left[{ }^{3} \mathrm{H}\right]$ dopamine and then preincubated for $20 \mathrm{~min}$ with various concentrations of $\alpha$-conotoxins before a 1 min pulse of $3 \mu \mathrm{M}$ nicotine plus toxin. Data are plotted as a percentage of nicotine-stimulated release (which is defined as $100 \%$ for control conditions, in which no antagonist was present). Concentrations of $\mathrm{MII} \geq 1 \mathrm{nM}$ produced significant block $(*)$ of nicotine-stimulated $\left[{ }^{3} \mathrm{H}\right] \mathrm{do}-$ pamine release $(1 \mathrm{nM}, p<.05 ; 10 \mathrm{nM}, p=.01 ; 100 \mathrm{nM}$ and $1 \mu \mathrm{M}, p<.001)$. Mecamylamine (mec; $100 \mu \mathrm{M})$ essentially completely blocked evoked dopamine release. In contrast, neither $1 \mu \mathrm{M}$ MI $(p=0.4)$ nor $1 \mu \mathrm{M} \mathrm{ImI}$ $(p=0.3)$ had detectable effect. Experiments were performed 3 to 13 times with 3 to 6 replicates per experiment.

subtype of nicotinic receptor (Johnson et al., 1995), had any effect on release (Fig. 2). Thus, the partial block of nicotine-evoked dopamine release by $\alpha$-conotoxin MII was the only significant inhibition of dopamine release by any $\alpha$-conotoxin.

\section{Effects of $\alpha$-conotoxin MII on different concentrations of nicotine-stimulated $\left[{ }^{3} \mathrm{H}\right]$ dopamine release}

Previous investigators who have examined the effects of $\kappa$-bungarotoxin on nicotine-stimulated dopamine release have reported variable results. One group reported that $\kappa$-bungarotoxin (100 nM) inhibited striatal dopamine release by $50 \%$ (Wonnacott et al., 1995). In contrast, other investigators reported that $\kappa$-bungarotoxin $(100 \mathrm{nM})$ completely blocked striatal dopamine release (Schulz and Zigmond, 1989; Grady et al., 1992). One difference between these studies is that the experiments in which $50 \%$ inhibition was observed used $3 \mu \mathrm{M}$ nicotine, whereas the experiments in which complete block was produced used 50 or 100 $\mu \mathrm{M}$ nicotine. This raises the possibility that high concentrations of nicotine reveal a distinct population of $\mathrm{nAChRs}$ with high affinity for $\kappa$-bungarotoxin (Wonnacott et al., 1995), although other experimental differences among laboratories may account for the results.

To be able to compare our results more fully with results reported previously using $\kappa$-bungarotoxin, we tested the effects of $\alpha$-conotoxin MII on dopamine release stimulated by $160 \mathrm{~nm}, 3$ $\mu \mathrm{M}$, and $100 \mu \mathrm{M}$ nicotine (Fig. 3A). $\alpha$-Conotoxin MII (100 nM) caused significant but partial block of the $\left[{ }^{3} \mathrm{H}\right]$ dopamine release at all nicotine concentrations tested. However, unlike the large differences in inhibition observed with $\kappa$-bungarotoxin, differences among the amount of block observed when nicotine levels change almost three orders of magnitude are relatively modest (Fig. 3B).

\section{Effects of $\alpha$-conotoxin MII on nicotine-stimulated norepinephrine release}

It has been reported previously that in synaptosomal preparations, nicotine releases hippocampal norepinephrine less potently than it does striatal dopamine $\left(\mathrm{EC}_{50}=6.5 \mathrm{vs} 0.16 \mu \mathrm{M}\right)$ (Clarke and Reuben, 1996). We used both $3 \mu \mathrm{M}$ and $100 \mu \mathrm{M}$ nicotine to 


\begin{tabular}{lllcl}
\hline \multicolumn{2}{l}{ Table 1. Selectivity of $\boldsymbol{\alpha}$-conotoxins } & & & \\
$\alpha$-CTx & Sequence* & nAChR & $\mathrm{IC}_{50}(\mathrm{nM})$ & Reference \\
\hline MII & GCCSNPVCHLEHSNLC & $\alpha 3 \beta 2$ & 0.5 & (Cartier et al., 1996a,b) \\
MI & GRCCHPACGKNYSC & $\alpha 1 \beta 1 \delta \gamma$ & 10 & (Johnson et al., 1995) \\
ImI & GCCSDPRCAWRC & $\alpha 7$ & 220 & (Johnson et al., 1995) \\
\hline
\end{tabular}

The disulfide bonding pattern is as follows:

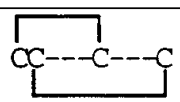

The structurally related $\alpha$-conotoxins are selective for the indicated nAChR subunits expressed in Xenopus oocytes. Clones for neuronal subunits were from rat and clones for muscle subunits were from mouse.

*The C-terminal $\alpha$-carboxyl group of all these peptides is amidated.
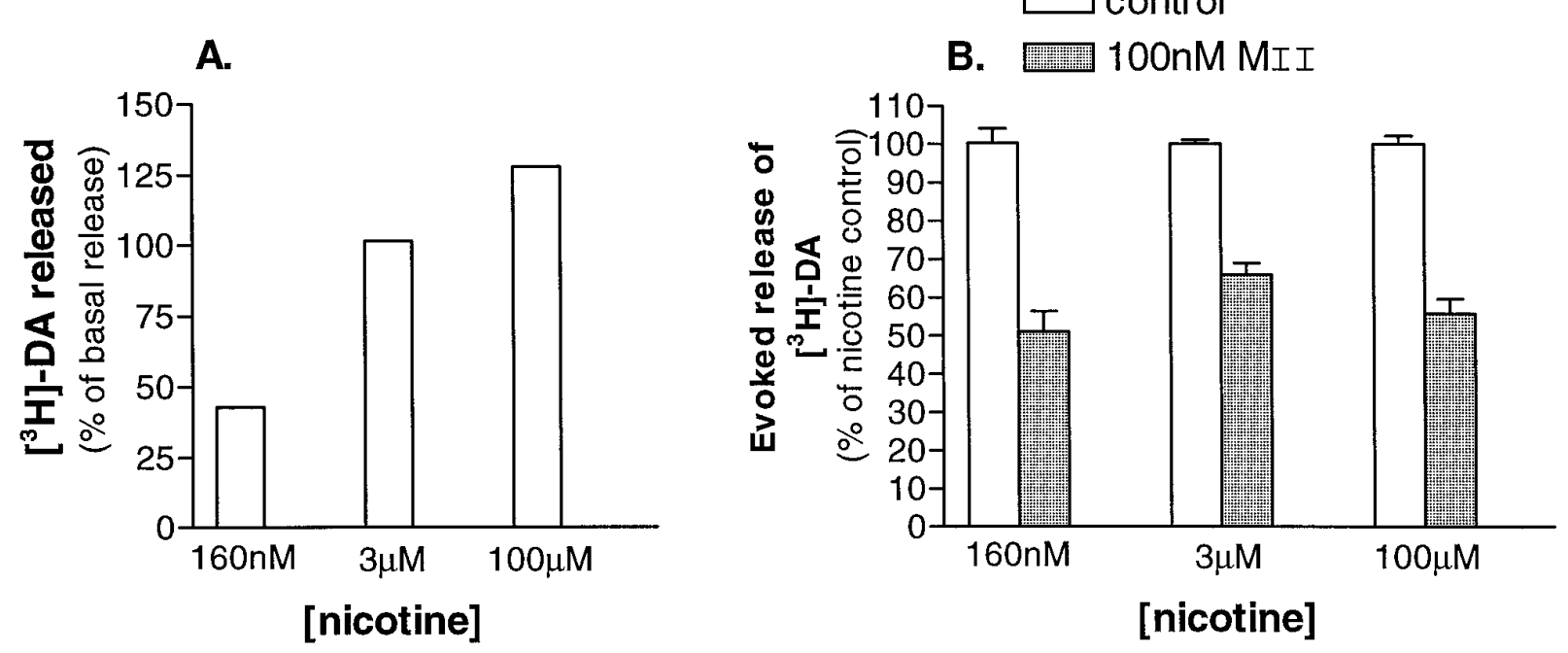

Figure 3. $\alpha$-Conotoxin MII blocks a fraction of nicotine-evoked dopamine release at various nicotine concentrations. $A$, Increasing concentrations of nicotine evoked progressively higher levels of $\left[{ }^{3} \mathrm{H}\right]$ dopamine release. The average amount of evoked $\left[{ }^{3} \mathrm{H}\right]$ dopamine release relative to basal $\left[{ }^{3} \mathrm{H}\right]$ dopamine release is shown. Nicotine at $100 \mu \mathrm{M}$ releases approximately threefold more dopamine than does $160 \mathrm{~nm}$ nicotine. $B$, The effect of 100 nM $\alpha$-conotoxin MII (shaded bars) was assessed over the range of nicotine concentrations used in $A$. Data are plotted as a percentage of nicotine-evoked release (which at each nicotine concentration is defined as 100\%). Block by $\alpha$-conotoxin MII ranged from 34 to $49 \%$ and was highly significant at all nicotine concentrations tested $(p<0.001)$. Experiments were performed 3 to 13 times with 3 to 8 replicates per experiment.

assay the effects of $\alpha$-conotoxin MII. Nicotine-evoked norepinephrine release is completely blocked by the nonspecific antagonist mecamylamine, and norepinephrine release is dependent on the presence of extracellular calcium (Fig. 4). In contrast to nicotine-stimulated dopamine release, $\alpha$-conotoxin MII blocked significantly less or failed to block norepinephrine release (Fig. 5). When the block of neurotransmitter release is compared, $100 \mathrm{~nm}$ $\alpha$-conotoxin MII (a concentration that primarily acts on $\alpha 3 \beta 2$ receptors) blocks significantly more dopamine than norepinephrine release across all tested nicotine concentrations $(p<0.001$ for all comparisons).

\section{DISCUSSION}

We have shown that $\alpha$-conotoxin MII causes a high-affinity, but partial, block of nicotine-stimulated dopamine release from rat striatal synaptosomes. In contrast, $\alpha$-conotoxin MII does not block dopamine release evoked by depolarization, indicating the toxin's specificity for nicotine-stimulated neurotransmitter release. $\alpha$-Conotoxin M II blocks rat $\alpha 3 \beta 2 \mathrm{nAChRs}$ expressed in Xenopus oocytes with an $\mathrm{IC}_{50}$ of $0.5 \mathrm{~nm}$. $\alpha$-Conotoxin MII also blocks other nAChR subunit combinations, but at concentrations that are two to four orders of magnitude higher, with the order of potency: $\alpha 3 \beta 2 \gg \alpha 7>$ $\alpha 4 \beta 2>\alpha 2 \beta 2 \cong \alpha 3 \beta 4>\alpha 1 \beta 1 \delta \gamma>\alpha 4 \beta 4 \geq \alpha 2 \beta 2$ (Cartier et al., 1996a,b; Harvey et al., 1997). At low nanomolar concentrations, $\alpha$-conotoxin MII blocks essentially only $\alpha 3 \beta 2$ receptors, strongly suggesting that the block of nicotine-stimulated dopamine release seen at these $\alpha$-conotoxin MII concentrations is attributable to block of native $\alpha 3 \beta 2$-containing nAChRs. Maximal M II block of nicotine-stimulated dopamine release is seen at $100 \mathrm{~nm}$ concentration with little additional block at $1 \mu \mathrm{M}$ concentration. These results suggest that some, but not all, nicotine-stimulated dopamine release is attributable to $\alpha 3 \beta 2$-containing nAChRs. Other nAChR subtypes presumably mediate the remainder of the response. Thus, more than one subtype of neuronal $\mathrm{nAChR}$ appears responsible for nicotine-stimulated dopamine release.

In contrast to nicotine-stimulated dopamine release, nanomolar concentrations of MII block substantially less or fail to block nicotine-stimulated norepinephrine release from rat hippocampal synaptosomes. Thus, $\alpha 3 \beta 2$-containing nAChRs appear to play a smaller or no role in nicotine-stimulated norepinephrine release from synaptosomes. It should be noted, however, that in slice preparations of hippocampus, a much larger percentage of nor- 

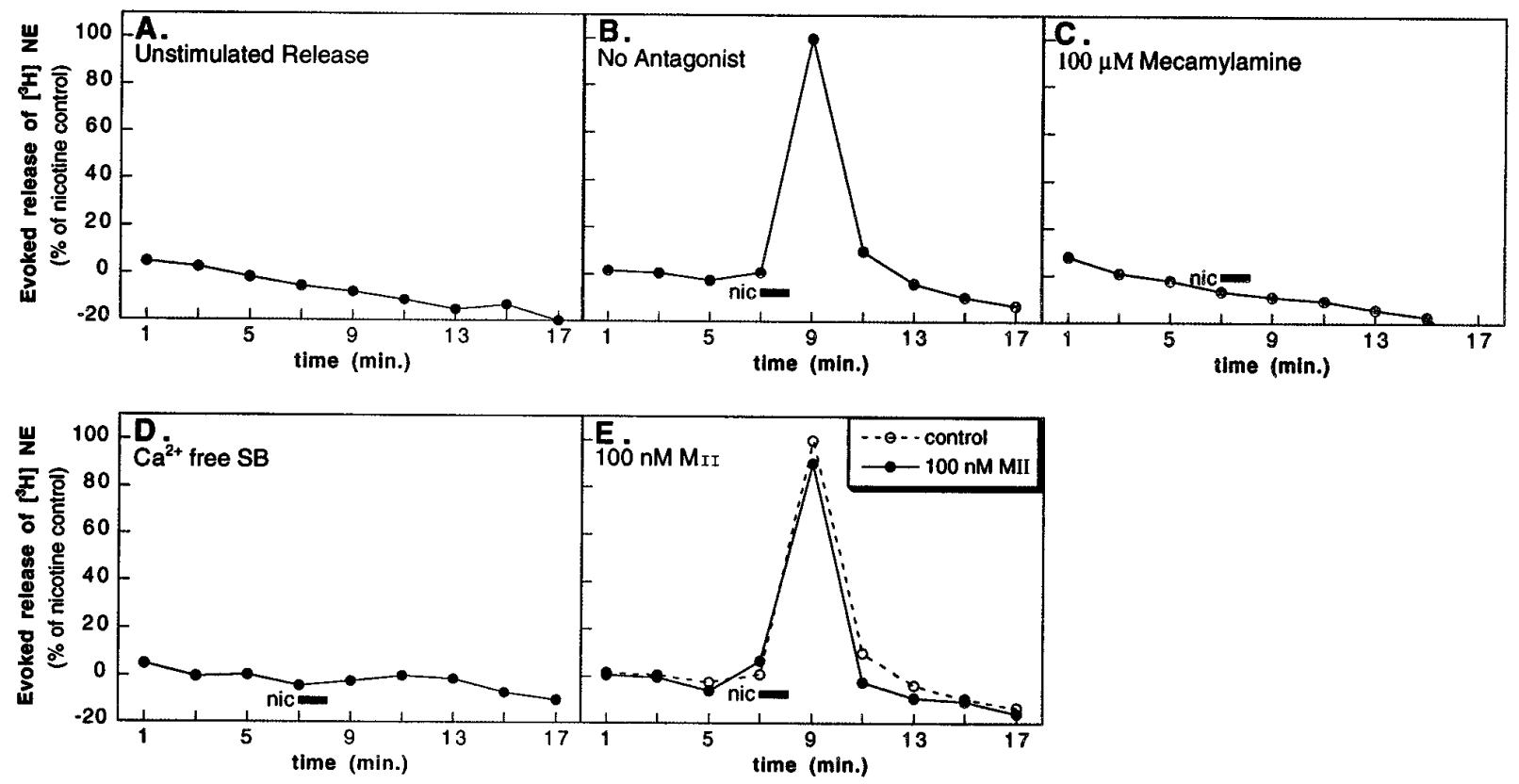

Figure 4. Nicotine-stimulated norepinephrine $(N E)$ release. Rat hippocampal synaptosomes were loaded with $\left[{ }^{3} \mathrm{H}\right]$ norepinephrine and perfused with buffer with or without antagonist for $20 \mathrm{~min}$ before sample collection. Nicotine-stimulated release is defined as $100 \%$, and the corresponding basal release at $t=9 \mathrm{~min}$ is defined as zero. Data are plotted as described in Figure 1. $A$, Unstimulated release of $\left[{ }^{3} \mathrm{H}\right]$ norepinephrine. $B,\left[{ }^{3} \mathrm{H}\right]$ norepinephrine release after a $1 \mathrm{~min}$ pulse of $100 \mu \mathrm{M}$ nicotine (horizontal bar in this and all subsequent panels). $C$, Nicotine-stimulated release in the presence of the nicotinic antagonist mecamylamine. $D$, Nicotine-stimulated release in the absence of $\mathrm{Ca}^{2+}$. $E, \alpha$-Conotoxin MII (100 nM) blocks $\sim 10 \%$ of nicotine-evoked release of $\left[{ }^{3} \mathrm{H}\right]$ norepinephrine.

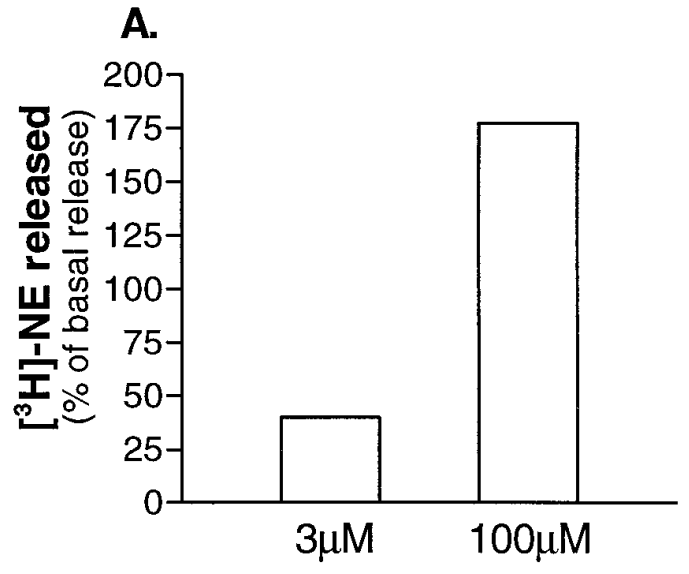

[nicotine]

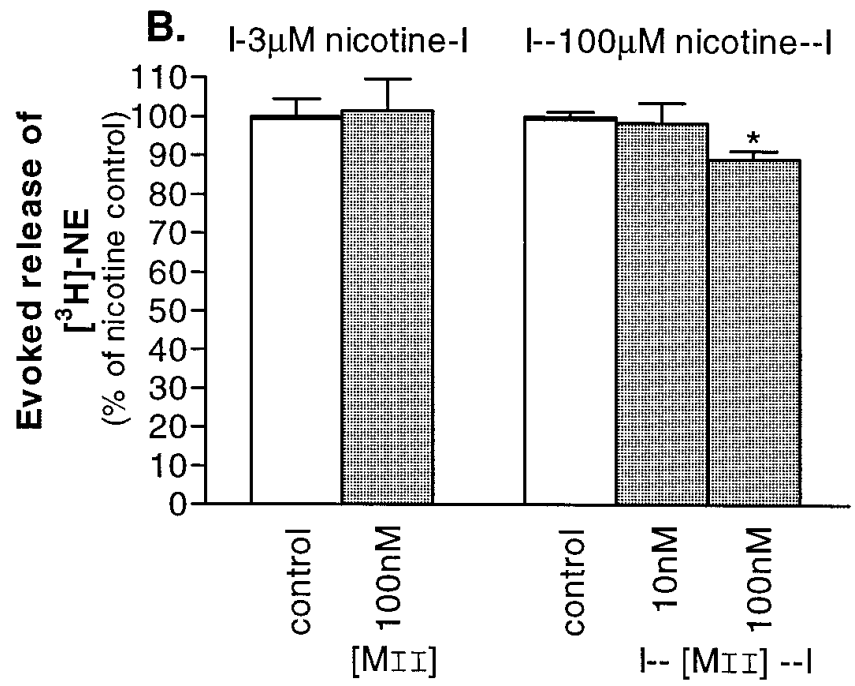

Figure 5. $\alpha$-Conotoxin MII's effect on nicotine-stimulated norepinephrine release from rat hippocampal synaptosomes. $A$, The average amount of nicotine-evoked relative to unstimulated (basal) $\left[{ }^{3} \mathrm{H}\right]$ norepinephrine release. Nicotine at $100 \mu \mathrm{M}$ concentration releases four- to fivefold more $\left[{ }^{3} \mathrm{H}\right]$ norepinephrine than it does at $3 \mu \mathrm{M}$. B. Synaptosomes were preincubated with or without antagonist for 20 min and then exposed to a 1 min pulse of either $3 \mu \mathrm{M}$ or $100 \mu \mathrm{M}$ nicotine \pm antagonist. Control nicotine-stimulated $\left[{ }^{3} \mathrm{H}\right]$ norepinephrine release is defined as $100 \%$ at each respective nicotine concentration. MII at $100 \mathrm{nM}$ fails to significantly block release evoked by $3 \mu \mathrm{M}$ nicotine $(p=0.4)$. Using $100 \mu \mathrm{M}$ nicotine, $10 \mathrm{nM}$ MII does not significantly block release $(p=0.25)$, but $100 \mathrm{~nm}$ MII blocked $10 \%$ of release $(p<0.05)$. Note that $100 \mathrm{~nm}$ MII blocks significantly more dopamine than norepinephrine release $(p<0.001$ for all nicotine concentrations tested; compare Fig. 2$)$. Experiments were performed three to four times with four to six replicates per experiment.

epinephrine is released by nicotine, e.g., $\sim 400 \%$ over basal (Sacaan et al., 1995) versus the $\sim 200 \%$ over basal release from synaptosome hippocampal preparations reported in this and other studies (Clarke and Reuben, 1996). Nicotine-stimulated release of either norepinephrine or dopamine from synaptosomes is not affected by the sodium channel blocker tetrodotoxin
(Clarke and Reuben, 1996). In contrast, tetrodotoxin does block the majority of nicotine-stimulated norepinephrine release from hippocampal slices (Sacaan et al., 1995), suggesting that at least some of the norepinephrine release is not attributable to nAChRs located on nerve terminals, but instead is dependent on propagated action potentials. It will be of interest in future studies to 

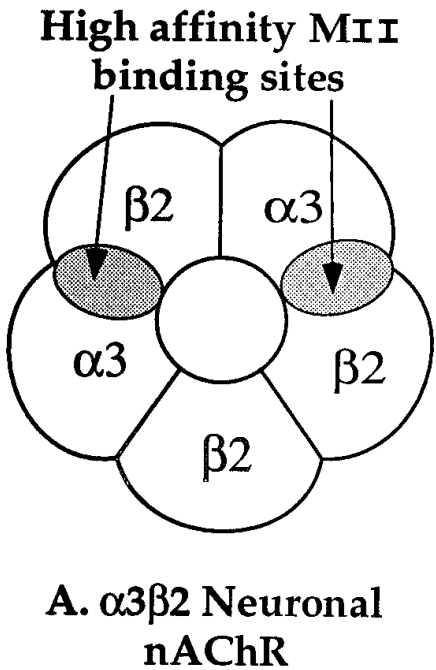

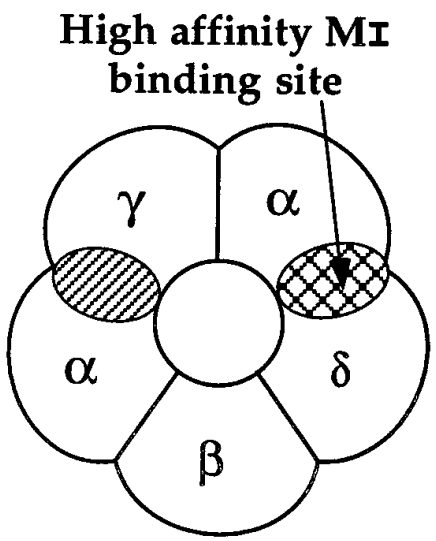

B. Muscle nAChR

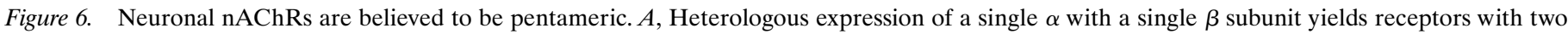

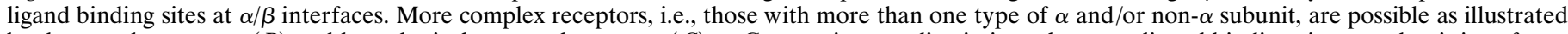

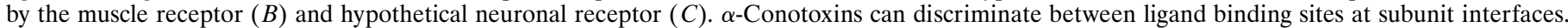

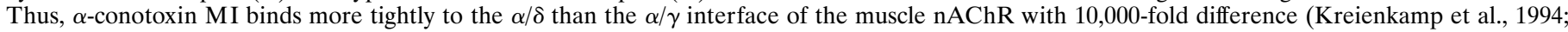

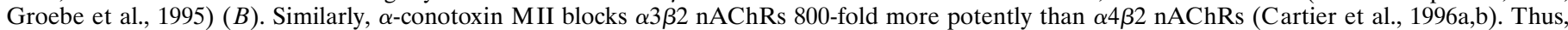

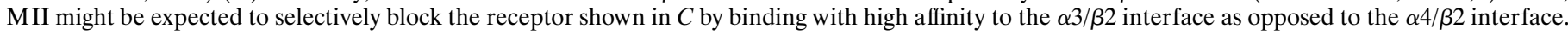

assess the effect of $\alpha$-conotoxin MII on tetrodotoxin-sensitive norepinephrine release.

Previous studies have addressed the identity of nAChR subtypes involved in nicotine-stimulated dopamine release. Several factors have made it difficult to unambiguously identify the relevant subtypes. First, there is a lack of subtype-specific antagonists for neuronal nAChRs. One antagonist, a minor component of Bungarus venom known as $\kappa$-bungarotoxin, has been used with some success in the study of nicotine-stimulated dopamine release. Under certain conditions, $\kappa$-bungarotoxin preferentially blocks $\alpha 3 \beta 2$ receptors (Luetje et al., 1990), although the presence of venom purification contaminants has led to inconsistent findings (Fiordalisi et al., 1994). In addition, it has been shown that $\kappa$-bungarotoxin blocks several subtypes of neuronal nAChRs, which was not initially appreciated because of the complex kinetics of this ligand (Papke et al., 1993). The ability of $\kappa$-bungarotoxin to selectively block $\alpha 3 \beta 2$ receptors or block multiple subtypes of nAChRs, depending on the conditions used, may help account for the reported differences in efficacy of this toxin in blocking nicotine-stimulated dopamine release.

Another approach used to examine nAChR subtypes has been to assess the potency of various nicotinic agonists in stimulating dopamine release and compare these potencies to the ability of these agonists in activating nAChRs heterologously expressed in Xenopus oocytes. One complicating factor with this approach is the possibility that more than one subtype of $\mathrm{nAChR}$ underlies nicotine-stimulated dopamine release. In such a case, the potency of a nicotinic agonist in stimulating dopamine release in brain tissue would not correlate with the agonist's potency in activating a single nAChR subtype. An even more complicated possibility is that native neuronal nAChRs are not simply a combination of a single type of $\alpha$ and $\beta$ subunit. For example, in chick ciliary ganglia, it appears that some neuronal nAChRs are composed of at least four types of subunits: $\alpha 3, \alpha 5, \beta 2$, and $\beta 4$ (Conroy and Berg, 1995). In general, nicotinic receptors require the binding of two molecules of acetylcholine to trigger channel opening. In muscle, the receptor-ligand binding sites are pharmacologically nonequivalent, being composed of an $\alpha 1 / \delta$ and an $\alpha 1 / \gamma$ interface. These two interfaces have different affinities for agonists. Similarly, both the $\alpha$ and $\beta$ subunits contribute to agonist sensitivity of neuronal nAChRs (Luetje and Patrick, 1991). Furthermore, it has been shown that nAChRs with two types of $\alpha$-subunits have different affinities for ACh than receptors with a single type of $\alpha$ subunit (Ramirez-Latorre et al., 1996; Wang et al., 1996). Thus, the presence of complex receptors in CNS tissue may not readily allow comparison of agonist potency with simple combinations of $\alpha$ and $\beta$ subunits in $\mathrm{nAChRs}$ expressed in Xenopus oocytes.

A particular advantage of $\alpha$-conotoxin antagonists is their ability to discriminate among nonsymmetrical ligand binding interfaces on nAChRs. The best-studied example is the binding of $\alpha$-conotoxin MI to the muscle nicotinic receptor (Fig. 6B). In mouse muscle, $\alpha$-conotoxin MI displays a four order-of-magnitude selectivity for the $\alpha 1 / \delta$ versus the $\alpha 1 / \gamma$ binding site (Kreienkamp et al., 1994; Groebe et al., 1995). Nevertheless, $\alpha$-conotoxin MI blocks muscle receptor function with an $\mathrm{IC}_{50}$ comparable to its $K_{\mathrm{d}}$ for the $\alpha 1 / \delta$ binding site, indicating that binding of only one toxin molecule is sufficient to block channel activation (Martinez et al., 1995). We have also demonstrated recently that $\alpha$-conotoxin MII has two binding sites on $\alpha 3 \beta 2$ and $\alpha 3 \beta 4$ receptors expressed in Xenopus oocytes, and binding of only one toxin molecule to a receptor is sufficient to block receptor function (Cartier et al., 1996b).

$\alpha$-Conotoxin MII has a lower $\mathrm{IC}_{50}$ for $\alpha 3 \beta 2$ than that for other receptor subunit combinations by two to four orders-ofmagnitude. Thus, $\alpha$-conotoxin MII, in theory, has the ability to potently block any receptor containing an $\alpha 3 / \beta 2$ subunit interface regardless of what other $\alpha$ and $\beta$ subunits may be in the receptor complex (Fig. 6). A receptor containing only one $\alpha 3 \beta 2$ interface (Fig. $6 C$ ) would be expected to have an $\mathrm{IC}_{50}$ approximately equal to the $K_{\mathrm{d}}$ of MII for the $\alpha 3 / \beta 2$ interface. It is possible, however, that the presence of other subunits could cause some structural alterations at the $\alpha 3 / \beta 2$ subunit interface, leading in turn to a somewhat altered affinity for MII. 
The results of the present study are consistent with the involvement of an nAChR that contains at least one $\alpha 3 / \beta 2$ subunit interface in nicotine-stimulated dopamine release. Additional dissection of the subunit composition of nAChRs involved in nicotine-stimulated dopamine release would be facilitated by additional nAChR subunit-specific antagonists. We are in the process of isolating and characterizing such agents.

Nicotinic acetylcholine receptors have been implicated in the treatment or pathophysiology of several neuropsychiatric disorders including schizophrenia (Freedman et al., 1994, 1997), Alzheimer's disease (Nordberg et al., 1989, 1990), Parkinson's disease (Janson et al., 1988; Reavill, 1990; Grandinetii et al., 1994), and Tourette's syndrome (Sandberg et al., 1988, 1989). Currently available neuropsychiatric medications work primarily by inhibiting neurotransmission through postsynaptic receptor antagonism or by inhibiting neurotransmitter reuptake or catabolism (Schatzberg et al., 1995). In particular, most presently used antipsychotic medications inhibit dopamine signaling by blocking postsynaptic dopamine receptors. The possibility of selectively modulating the presynaptic release of dopamine has significant therapeutic implications. Our data, which suggest that dopamine release is mediated by two or more distinct subtypes of nAChRs, indicate that the cholinergic modulation of dopamine release may be highly complex, presenting opportunities for pharmacological intervention. Thus, by blocking presynaptic nAChRs, it might prove possible to attenuate, but not completely abolish, dopamine release. In principle, this could lead to an antipsychotic strategy with fewer side-effects than complete postsynaptic blockade.

\section{REFERENCES}

Cartier GE, Yoshikami D, Gray WR, Luo S, Olivera BM, McIntosh JM (1996a) A new $\alpha$-conotoxin which targets $\alpha 3 \beta 2$ nicotinic acetylcholine receptors. J Biol Chem 271:7522-7528.

Cartier GE, Yoshikami D, Luo S, Olivera BM, McIntosh JM (1996b) $\alpha$-Conotoxin MII ( $\alpha$-Ctx-MII) interaction with neuronal nicotinic acetylcholine receptors. Soc Neurosci Abstr 22:268.

Clarke PBS, Reuben M (1996) Release of $\left[{ }^{3} \mathrm{H}\right]$-noradrenaline from rat hippocampal synaptosomes by nicotine: mediation by different nicotinic receptor subtypes from striatal $\left[{ }^{3} \mathrm{H}\right]$-dopamine release. $\mathrm{Br} \mathrm{J}$ Pharmacol 111:695-702.

Conroy WG, Berg DK (1995) Neurons can maintain multiple classes of nicotinic acetylcholine receptors distinguished by different subunit compositions. J Biol Chem 270:4424-4431.

Di Chiara G (1995) The role of dopamine in drug abuse viewed from the perspective of its role in motivation. Drug Alcohol Depend 38:95-137.

El-Bizri H, Clarke PBS (1994) Blockade of nicotine receptor-mediated release of dopamine from striatal synaptosomes by chlorisondamine and other nicotinic antagonists administered in vitro. Br J Pharmacol 111:406-413.

Fiordalisi JJ, Al-Rabiee R, Chiappinelli VA, Grant GA (1994) Affinity of native $\kappa$-bungarotoxin and site-directed mutants for the muscle nicotinic acetylcholine receptor. Biochemistry 33:12962-12967.

Freedman R, Adler LE, Bickford P, Byerley W, Coon H, Cullum CM, Griffith JM, Harris JG, Leonard S, Miller C, Myles-Worsley M, Nagamoto HT, Rose G, Waldo M (1994) Schizophrenia and nicotinic receptors. Harvard Rev Psychiatry 2:179-192.

Freedman R, Coon H, Myles-Worsley M, Orr-Urtreger A, Olincy A, Davis A, Polymeropoulos M, Holik J, Hopkins J, Hoff M, Rosenthal J, Waldo MC, Reimherr F, Wender P, Yaw J, Young DA, Breese CR, Adams C, Patterson D, Adler LE, Kruglyak L, Leonard S, Byerley W (1997) Linkage of a neurophysiological deficit in schizophrenia to a chromosome 15 locus. Proc Natl Acad Sci USA 94:587-592.

Grady S, Marks M, Wonnacott S, Collins AC (1992) Characterization of nicotinic receptor mediated $\left[{ }^{3} \mathrm{H}\right]$ dopamine release from synaptosomes prepared from mouse striatum. J Neurochem 59:848-856.

Grandinetii A, Morens DM, Reed D, MacEachem D (1994) Prospective study of cigarette smoking and the risk of developing idiopathic Parkinson's disease. Am J Epidemiol 139:1129-1138.

Gray R, Rajan AS, Radcliffe KA, Yakehiro M, Dani JA (1996) Hippocampal synaptic transmission enhanced by low concentrations of nicotine. Nature 383:713-716.

Groebe DR, Dumm JM, Levitan ES, Abramson SN (1995) $\alpha$-Conotoxins selectively inhibit one of the two acetylcholine binding sites of nicotinic receptors. Mol Pharmacol 48:105-111.

Harvey SC, McIntosh JM, Cartier GE, Maddox FN, Luetje CW (1997) Determinants of specificity for $\alpha$-conotoxin MII on $\alpha 3 \beta 2$ neuronal nicotinic receptors. Mol Pharmacol 51:336-342.

Janson AM, Fuxe K, Sundstrom E, Agnati LF, Golstgein M (1988) Chronic nicotine treatment partly protects against the 1-methyl-4phenyl-1,2,3,6-tetrahydropyridine-induced degeneration of nigrostriatal dopamine neurons in the black mouse. Acta Physiol Scand 132:589-591.

Johnson DS, Martinez J, Elgoyhen AB, Heinemann SS, McIntosh JM (1995) $\alpha$-Conotoxin ImI exhibits subtype-specific nicotinic acetylcholine receptor blockade: preferential inhibition of homomeric $\alpha 7$ and $\alpha 9$ receptors. Mol Pharmacol 48:194-199.

Koob G (1992) Drugs of abuse: anatomy, pharmacology and function of reward pathways. Trends Pharmacol Sci 13:177-184.

Kreienkamp H-J, Sine SM, Maeda RK, Taylor P (1994) Glycosylation sites selectively interface with $\alpha$-toxin binding to the nicotinic acetylcholine receptor. J Biol Chem 269:8108-8114.

Lapchak PA, Araujo DM, Quirion R, Collier B (1989) Effect of chronic nicotine treatment on nicotinic autoreceptor function and $\mathrm{N}-\left[{ }^{3} \mathrm{H}\right]$ methylcarbamycholine binding sites in rat brain. J Neurochem 52:483-491.

Luetje CW, Patrick J (1991) Both $\alpha$ - and $\beta$-subunits contribute to the agonist sensitivity of neuronal nicotinic acetylcholine receptors. J Neurosci 11:837-845.

Luetje CW, Wada K, Rogers S, Abramson SN, Tsuji K, Heinemann S, Patrick J (1990) Neurotoxins distinguish between different neuronal nicotinic acetylcholine receptor subunit combinations. J Neurochem 55:632-640.

Martinez JS, Olivera BM, Gray WR, Craig AG, Groebe DR, Abramson SN, McIntosh JM (1995) $\alpha$-Conotoxin EI, a new nicotinic acetylcholine receptor-targeted peptide. Biochemistry 34:14519-14526.

McGehee DS, Role LW (1995) Physiological diversity of nicotinic acetylcholine receptors expressed by vertebrate neurons. Annu Rev Physiol 57:521-546.

Mulle C, Vidal C, Benoit P, Changeux J-P (1991) Existence of different subtypes of nicotinic acetylcholine receptors in the rat habenulointerpeduncular system. J Neurosci 11:2588-2597.

Nordberg A, Nilsson-Håkansson L, Adem A, Hardy J, Alafuzoff I, Lai Z, Herrera-Marschitz M, Winblad B (1989) The role of nicotinic receptors in the pathophysiology of Alzheimer's disease. Prog Brain Res 79:353-362.

Nordberg A, Hartvig P, Lilja A, Viitanen M, Amberla K, Lundovist H, Andersson T, Ulin J, Winblad B, Långström B (1990) Decreased uptake and binding of ${ }^{11} \mathrm{C}$-nicotine into the brain of Alzheimer patients as visualized by positron emission tomography. J Neural Transm 2:215-224.

Papke RL, Duvoisin RM, Heinemann SF (1993) The amino terminal half of the nicotinic $\beta$-subunit extracellular domain regulates the kinetics of inhibition by neuronal bungarotoxin. Proc R Soc Lond [Biol] 252:141-148.

Papke RL, Craig AG, Heinemann SF (1994) Inhibition of nicotinic acetylcholine receptors by bis(2,2,6,6-tetramethyl4r-piperidinyl) sebacate (Tinuvin 770), an additive to medical plastics. J Pharmacol Exp Ther 268:718-726.

Pontieri FE, Tanda G, Orzi F, Di Chiara G (1996) Effects of nicotine on the nucleus accumbens and similarity to those of addictive drugs. Nature 382:255-257.

Ramirez-Latorre J, Yu CR, Qu X, Perin F, Karlin A, Role L (1996) Functional contributions of $\alpha 5$ subunit to neuronal acetylcholine receptor channels. Nature 380:347-351.

Rapier C, Lunt GG, Wonnacott S (1988) Stereoselective nicotineinduced release of dopamine from striatal synaptosomes: concentration dependence and repetitive stimulation. J Neurochem 50:1123-1130.

Reavill C (1990) Action of nicotine on dopamine pathways and implications for Parkinson's disease. In: Molecular, cellular and behavioural aspects (Russell MAH, Stolerman IP, eds), pp Oxford: Oxford UP.

Rowell PP, Winkler DL (1984) Nicotinic stimulation of $\left[{ }^{3} \mathrm{H}\right]$ acetylcho- 
line release from mouse cerebral cortical synaptosomes. J Neurochem 43:1593-1598.

Sacaan AI, Dunlop JL, Lloyd GK (1995) Pharmacological characterization of neuronal acetylcholine gated ion channel receptor-mediated hippocampal norepinephrine and striatal dopamine release from rat brain slices. J Pharmacol Exp Ther 274:224-230.

Sandberg PR, Fogelson HM, Manderscheid PZ, Parker KW, Norman AB, McConville BJ (1988) Nicotine gum and haloperidol in Tourette's syndrome. Lancet 12:592.

Sandberg PR, McConville BJ, Fogelson HM, Manderscheid PZ, Parker KW, Blythe MM, Klykylo WM, Norman AB (1989) Nicotine potentiates the effects of haloperidol in animals and in patients with Tourette's syndrome. Biomed Pharmacother 43:19-23.

Schatzberg AF, Nemeroff CB (1995) Section II: classes of psychiatric drugs: animal and human pharmacology. In: Textbook of pharmacology (Meltzer HY, ed), pp 141-438. Washington, DC: American Psychiatric.

Schulz DW, Zigmond RE (1989) Neuronal bungarotoxin blocks the nicotinic stimulation of endogenous dopamine release from rat striatum. Neurosci Lett 98:310-316.

Vidal C, Changeux J-P (1993) Nicotinic and muscarinic modulations of excitatory synaptic transmission in the rat prefrontal cortex. Neuroscience 56:23-32.

Wang F, Gerzanich V, Wells GB, Anand R, Peng X, Keyser K, Lindstrom $\mathrm{J}$ (1996) Assembly of human neuronal nicotinic receptor $\alpha 5$ subunits with $\alpha 3, \beta 2$ and $\beta 4$ subunits. J Biol Chem 271: 17656-17665.

Wilkie GI, Stephens MW, Hutson PJ, Whiting P, Wonnacott S (1993) Hippocampal nicotinic autoreceptors modulate acetylcholine release. Biochem Soc Trans 21:429-431.

Wonnacott S (1997) Presynaptic nicotinic ACh receptors. Trends Neurosci 20:92-98.

Wonnacott S, Wilkie G, Soliakov L, Whiteaker P (1995) Presynaptic nicotinic autoreceptors and heteroreceptors in the CNS. In: Effects of nicotine on biological systems II (Clarke PBS, Quik M, Adlkofer F, Thurau K, eds), pp 87-94. Basel: Birkhäuser. 